\title{
Isolated Cecal Necrosis in a Patient With Chronic Renal Failure
}

\author{
Kronik Böbrek Yetmezliği Olan Hastada İole Çekum \\ Nekrozu
}

Olgu Sunumu Case Report

Alındığı tarih: 11.06 .2018 Kabul tarihi: 11.09.2018 Online Yayın tarihi: 26.03.2019

Gizem Kılınç S.B.Ü. İzmir Tepecik Eğitim ve Araştırma Hastanesi Genel Cerrahi, İzmir, Türkiye drgizemkilinc@gmail.com ORCiD: 0000-0002-6987-3198

B. Balcı 0000-0002-0630-5097 K. Tuncer 0000-0001-7458-828X H. Öğücü 0000-0003-4089-1162 M. Emiroğlu 0000-0002-4968-2570 S.B.Ü. Tepecik Eğitim ve Araştırma Hastanesi Genel Cerrahi Anabilim Dalı, izmir, Türkiye

Cite as: Klııç G, Balcı B, Tuncer K, Öğücü H, Emiroğlu M. Isolated cecal necrosis in a patient with chronic renal failure. Tepecik Ë̆it. ve Arașt. Hast. Dergisi. 2019;29(1):95-8.

\section{Gizem Kılınç $\oplus$, Bengi Balcı $\odot$, Korhan Tuncer $\odot$, Hakan Öğücü $\odot$, Mustafa Emiroğlu $\odot$}

\begin{abstract}
Nonocclusive acute colonic ischemia is frequently seen in elderly population due to low blood flow and clinically it is presented with right lower quadrant abdominal pain mimicking acute appendicitis. Physical examination; blood tests, radiologic examinations and endoscopic procedures are helpful on the way to diagnosis. Although many operative techniques have been reported, right hemicolectomy with anastomosis is the most prefered surgical procedure.

A 58-year-old male who had appendectomy 4 months ago, presented with right lower quadrant abdominal pain and rectal bleeding. The patient with the diagnosis of chronic renal failure had been on hemodialysis program for three times a week for 5 years. Following physical examination, colonoscopy was performed and patient was diagnosed as cecal necrosis. Patient underwent emergent operation, and right hemicolectomy along with ileotransversostomy was performed On postoperative day 9, patient was discharged without development of any postoperative complications.

Although isolated cecal necrosis is a rare condition this pathology should be kept in mind in patients with chronic heart disease, chronic renal failure on routine hemodialysis program.
\end{abstract}

Keywords: Isolated cecal necrosis, chronic renal failure, acute colonic ischemia

öz

Non-okluziv akut kolonik iskemi düşük kan akımına bağlı olarak sıklıkla yaşlı populasyonda görülen ve sağ alt kadran karın ağrısı semptomu ile başlayarak apandisiti taklit eden bir patolojidir. Fizik muayene, laboratuvar testleri, radyolojik testler ve endoskopik yöntemler tanıya giden yolda yardımcıdır. Sağ hemikolektomiyi takiben yapılan ileotransversostomi genelde yeğlenen operasyon tekniği olmakla beraber, birçok operasyon tekniği tanımlanmıştir.

Elli sekiz yaş erkek hasta 4 ay önce apendektomi öyküsü olup, sağ alt kadran karın ağrısı ve rektal kanama yakınması ile başvuruyor. Kronik böbrek yetmezliği tanısı olan hasta 5 yıldır haftada 3 gün olmak üzere hemodiyaliz almaktadır. Fizik muayeneyi takiben hastaya kolonoskopi yapılmış olup, hasta çekum nekrozu tanısı almıştır. Hasta acil olarak operasyona alınmış ve sağ hemikolektomi ile beraber ileotransversostomi yapılmıştır. Postoperatif 9. günde hasta hiçbir komplikasyon gelişmeksizin taburcu edilmiştir.

izole çekum nekrozu nadir görülen bir durum olmakla beraber, kronik kalp hastalığı, kronik böbrek yetmezliği olup, hemodiyaliz programında olan hastalarda akılda bulundurulmalıdır.

Anahtar kelimeler: İzole çekum nekrozu, kronik böbrek yetmezliği, akut kolonik iskemi

\section{INTRODUCTION}

Acute colonic ischemia is usually seen in the elderly population as a result of atherosclerosis and low blood flow which can cause colitis and rectal bleeding. Acute nonocclusive ischemia of the colon manifested as isolated cecal necrosis is a rare condition which mostly occurs in patients with chronic renal failure or heart failure and $9 \%$ to $20 \%$ of deaths in hemodialysis dependent patients are attributable to nonocclusive mesenteric ischemia or bowel infarction ${ }^{(1-3)}$. Although there is not a consensus on gender and the age of the pati-
(C) Telif hakkı TC. Să̆lık Bakanlığı İmir Tepecik Eğit. ve Arastt. Hastanesi. Logos Tıp Yayınclık tarafindan yayınlanmaktadır.

Bu dergide yayınlanan bütün makaleler Creative Commons Atf-GayriTicari 4.0 Uluslararası Lisansı ile lisanslanmıştır.

(c) Copyright Association of Publication of the T.C. Ministry of Health Izmir Tepecik Education and Research Hospital.

This journal published by Logos Medical Publishing.

Licenced by Creative Commons Attribution-NonCommercial 4.0 International (CC BY-NC 4.0) 
ents under chronic dialysis presenting with nonocclusive mesenteric ischemia, Yaacov Ori et al. (4) reported the mean age of the patients as $70.8 \pm 1.8$ years, and the male:female ratio of $7: 13$ in these patients. In the same study possible contributing factors for nonocclusive mesenteric ischemia other than dialysis- associated hypotension were reported as high-dose recombinant human erythropoietin therapy, metastatic calcifications in abdominal aorta, digoxin treatment, and hypoalbuminemia. Patients who have isolated cecal necrosis usually present with right lower quadrant abdominal pain, nausea and vomiting resembling acute appendicitis. Here, we report a 58-year-old male patient with known chronic renal failure who was diagnosed with cecal necrosis and underwent a right hemicolectomy operation.

\section{CASE REPORT}

A 58-year-old male patient applied to the emergency clinic with right lower quadrant abdominal pain and rectal bleeding ongoing for three days. The patient had undergone appendectomy 4 months ago which pathological examination was reported as reactive lymphoid hyperplasia with melanosis coli. The patient had been diagnosed with chronic renal failure 5 years ago, and had been on hemodialysis program for three times a week. The patient had no other symptoms such as vomiting, nausea, and diarrhea. On physical examination, the patient's body temperature, blood pressure, and heart rate were within their normal ranges. The patient had abdominal distention with guarding and rebound on the right lower quadrant. Bowel sounds were found to be minimally decreased. On rectal examination hematochezia was present. Following the physical examination, laboratory tests including complete blood count ( $C B C)$, biochemical and coagulation tests, arterial blood gas analyses were performed. Laboratory tests were found to be normal except increased creatinine levels. To investigate the source of gastrointestinal bleeding, colonoscopic examination and
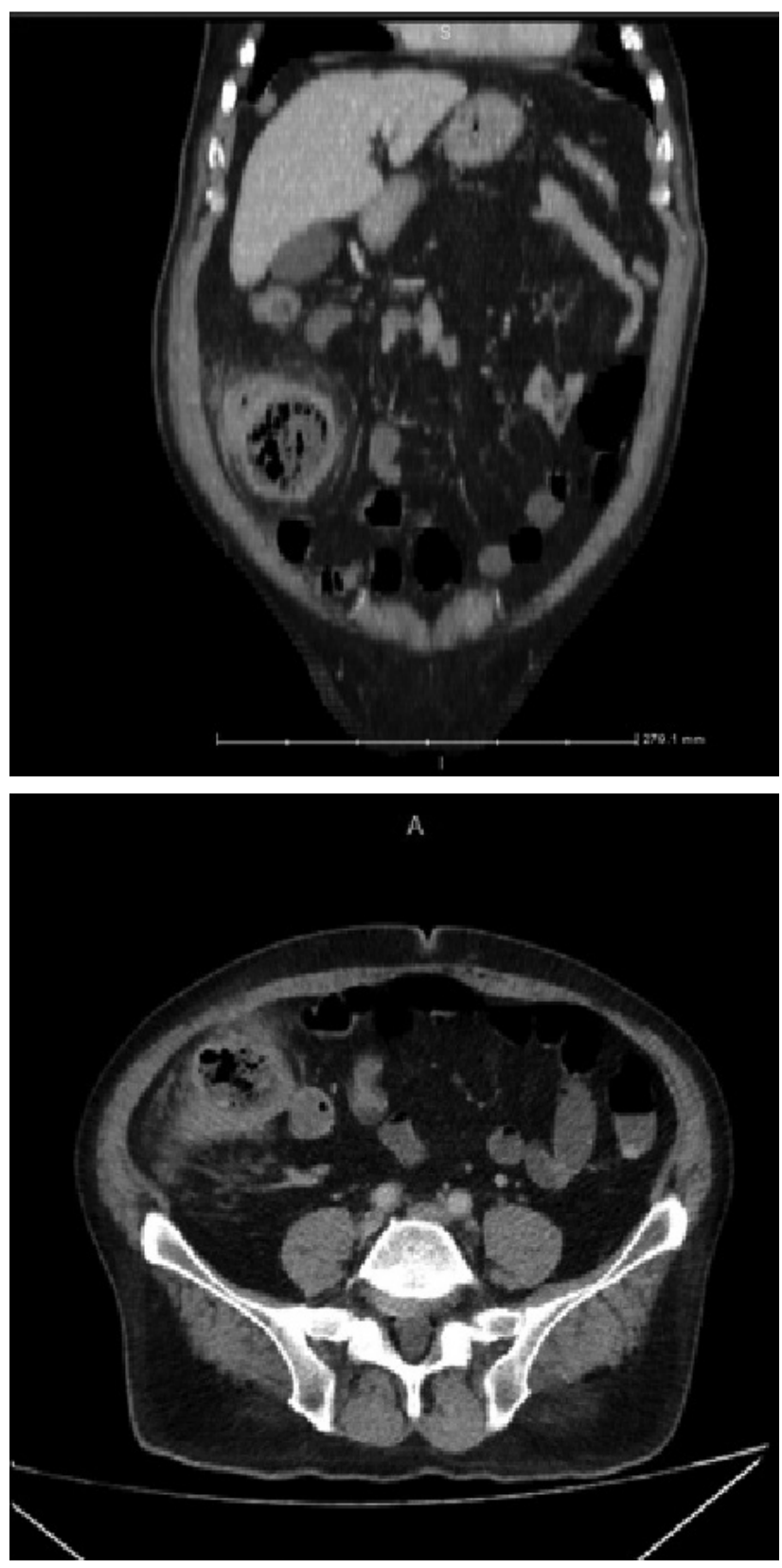

Figure 1-2. Abdominal CT scan image that shows thickened cecal wall, pericecal fluid, and heterogeneity.

computed tomography (CT) of the abdomen were performed. Abdominal CT scan demonstrated thickened cecal wall with pericecal fluid (Figure 1,2).

On colonoscopic examination, an ulcerated cecal lesion with clots and ischemic areas was detected. Other segments of the colon were found to be normal and no other active bleeding areas were seen. With the presumptive diagnosis of colonic ischemia, 

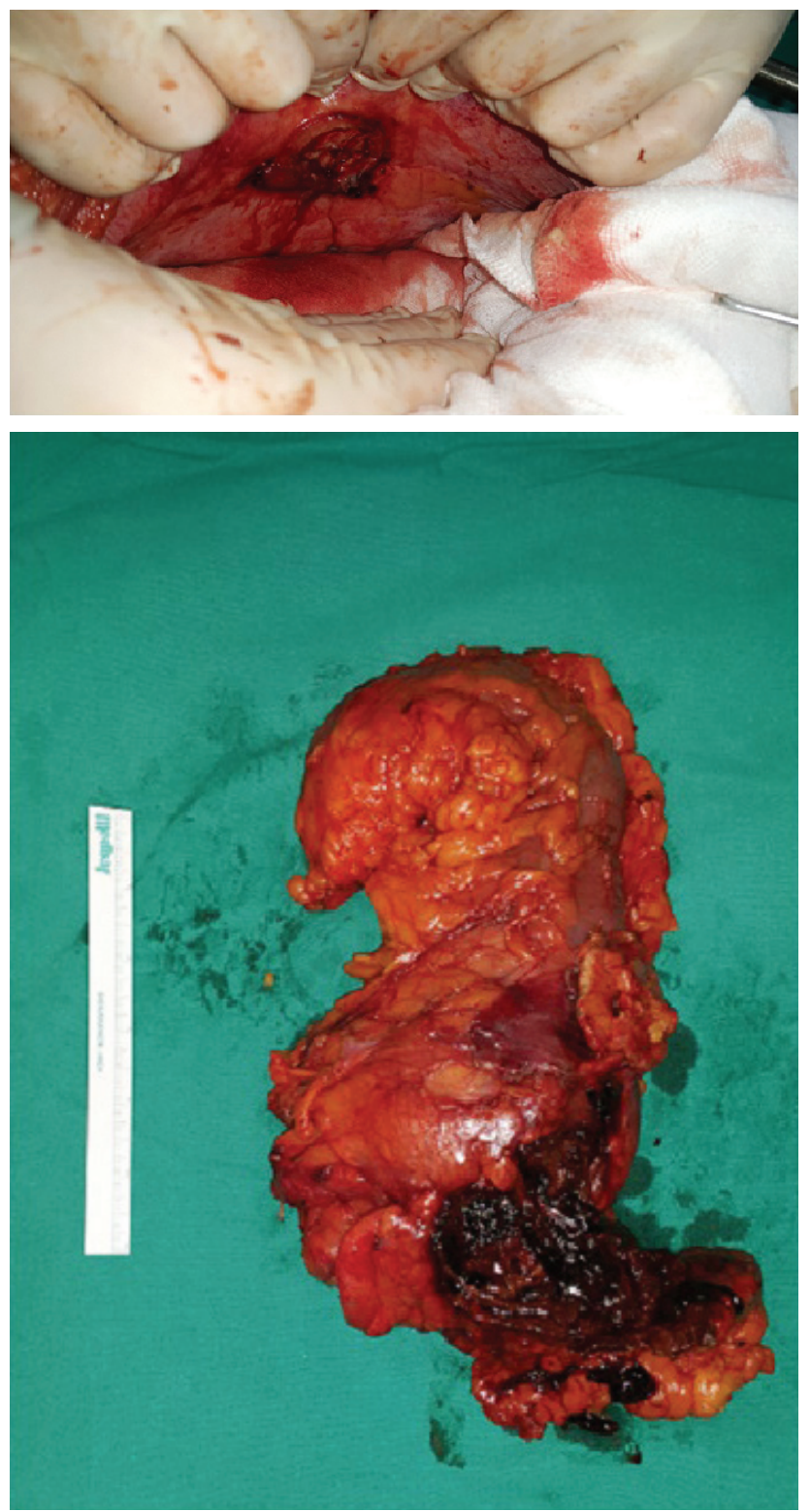

Figure 3-4. Right hemicolectomy specimen shows cecal necrosis with 5 $\mathrm{cm}$ perforated area.

the patient was hospitalized for an emergent operation. Under general anesthesia with endotracheal intubation explorative laparotomy was performed. It was seen that cecal wall was perforated in the area of ischemia and partially closed by an anterior abdominal wall (Figure 3,4).

The right hemicolectomy with side to side ileotransversostomy was performed. The patient was started on broad-spectrum antibiotics and then levels of inflammatory markers gradually decreased. The pati- ent was started on liquids, and solid food on a postoperative days 3 , and 5 , respectively. The patient was discharged on postoperative day 9.

Histopathological examination revealed diffuse mucosal ulceration and inflammation reaching to subserosal layer. All dissected lymph nodes were found to be reactive.

\section{DISCUSSION}

Intestinal ischemia is divided into three groups as acute mesenteric ischemia, chronic mesenteric ischemia and colonic ischemia (ischemic colitis). Although the most frequently seen form of intestinal ischemia is colonic ischemia, isolated cecal necrosis is a rare entity which can occur due to occlusive or nonocclusive pathologies. It has been shown that nonocclusive isolated cecal necrosis is associated with open heart surgery, chronic heart disease, chronic renal failure and hemodialysis ${ }^{(5,6,8)}$. The physiopathology is based on low blood flow and patients on routine hemodialysis program have a greater risk for ischemic colitis due to increased incidence of arterial vascular diseases.

Patients who have isolated cecal necrosis, usually present with right lower quadrant abdominal pain, nausea, vomiting, fever which may be easily misinterpreted as acute appendicitis. Patients may also have symptoms such as rectal bleeding and diarrhea consistent with colitis. Laboratory tests, colonoscopic and radiological examinations are important on the way to diagnosis. Leukocytosis, necrotic cecal mucosa in colonoscopy, thickened cecal wall, increased diffuse intestinal diameter, mesenteric arterial thrombus, intestinal pneumatosis, portal or mesenteric venous gas, pneumoperitoneum and intraabdominal free fluid may be found in CT scans ${ }^{(9,10)}$.

In the literature, there are different types of surgical methods recommended for the management of isolated cecal necrosis. Although in many studies right 
hemicolectomy with ileotransversostomy was recommended, construction of ileostomy following cecal resection or other surgical procedures such as cecal tube and cecostomy according to the size of the cecal perforation and necrosis can also be performed ${ }^{(5-7)}$.

Isolated cecal necrosis is a rare condition which can occur in patients with chronic renal and heart failure, thus it should be considered in patients presenting with right lower quadrant abdominal pain.

Ethics Committee Approval: No ethics committee approval was received due to the patient's informed consent.

Conflict of Interest: There is no conflict of interest related to any person and / or institution.

Funding: There is no funding was received from any person and / or institution.

Informed Consent: Informed consent was taken from the patient.

Etik Kurul Onayı: Hastanın bilgilendirilmiş onamı alındığı için etik kurul onayı alınmadı.

Çıkar Çatışması: Herhangi bir kişi ve / veya kurumla ilgili herhangi bir çıkar çatı̧̧ması yoktur.

Finansal Destek: Herhangi bir kişi ve / veya kurumdan herhangi bir finansal destek alınmamıştır.

Hasta Onamı: Hastadan bilgilendirilmiş onam alındı.

\section{REFERENCES}

1. Gundes E, Kucukkartallar T, Çolak MH, Cakir M, and Aksoy F. Ischemic necrosis of the cecum: A single center experience. Korean J Gastroenterol. 2013;61(5):265-9. [CrossRef]

2. Beck DE, de Aguilar-Nascimento JE. Surgical management and outcome in acute ischemic colitis. Ochsner J. 2011;11:282-5.

3. Çakar E, Ersöz F, Bag M ve ark. Isolated cecal necrosis: our surgical experience and a review of the literature. Ulusal Cer Derg. 2014;30:214-8.

4. Ori Y, Chagnac A, Schwartz A, et al. Non-occlusive mesenteric ischemia in chronically dialyzed patients: A disease with multiple risk factors. Nephron Clin Pract. 2005;101:c87-c93 [CrossRef]

5. Dirican A, Unal B, Bassulu N, Tatlı F, Aydin C, Kayaalp C. Isolated cecal necrosis mimicking acute appendicitis: a case series. J Med Case Rep. 2009;3:7443-7. [CrossRef]

6. Kiyak G, Ozgün Y, Sarikaya SM, Korukluoğlu B. Isolated cecal necrosis mimicking acute appendicitis. Turk J Gastroenterol. 2008;19:71-2.

7. Rist CB, Watts JC, Lucas RJ. Isolated ischemic necrosis of the cecum in patients with chronic heart disease. Dis Colon Rectum. 1984;27:548-51. [CrossRef] https://doi.org/10.1007/BF02555524

8. Hargrove WC 3rd, Rosato EF, Hicks RE, Mullen JL. Cecal necrosis after open-heart operation. Ann Thorac Surg. 1978;25:71-3. [CrossRef]

9. Simon AM, Birnbaum BA, Jacobs JE. Isolated infarction of the cecum:CTfindings in two patients. Radiology. 2000;214:513-6. [CrossRef]

10. Hoeffel C, Crema MD, Belkacem A, et al. Multi-detector row CT: spectrum of diseases involving the ileocecal area. Radiographics. 2006;26:1373-90. [CrossRef] 